\title{
Analysis of Gold Investment in Islamic Banking: Quantitative Simulation of Gold Farming
}

\author{
Sulistyowati \\ Indonesia Banking School \\ sulis@ibs.ac.id
}

Abstract

This analyzes gold investment in Islamic banking: quantitative simulation of gold farming. It uses secondary data, which are qardh financing for gold pawning, gold price per troy ounce per USD also rupiah exchange rate per USD and using quantitative simulation technique with mathematics method. There are several funding from this research. Firstly, gold farming practices can cause losses, especially in lag four. It is caused by world gold prices fluctuations and the volatility of the rupiah exchange rate. Secondly, the amount of losses and profits every month and year is different in each lag execution among lag 1 , lag 2, lag 3 and lag 4 months. Thirdly, a comparison result shows that frequency of losses and profits each year during simulation period causes difference final values of losses and profits. Based on simulation in this research, there are several things determining gold farming practices. They are gold value, Financing to Value (FTV) ratio, lag and the amount of pawned gold. So, it must be regulated or restricted by the regulator to prevent the customer doing gold farming practices in Islamic banks.

Keywords: Gold pawning, Gold farming, Financing to Value (FTV) and Lag.

Tesis ini menganalisis investasi emas di perbankan syariah: simulasi kuantitatif pertanian emas. Dengan menggunakan data sekunder, yaitu pembiayaan qardh untuk gadai emas, emas harga per troy ounce per USD juga rupiah kurs per USD and menggunakan teknik simulasi kuantitatif dengan metode matematika. Ada beberapa sumber penandaan dari penelitian ini. Pertama, praktik pertanian emas dapat menyebabkan kerugian, terutama di lag empat. Hal ini disebabkan oleh fluktuasi harga emas dunia and volatilitas nilai tukar rupiah. Kedua, jumlah kerugian and keuntungan setiap bulan and tahun berbeda dalam setiap pelaksanaan lag antara lag 1, lag 2, tertinggal 3 and lag 4 bulan. Ketiga, hasil perbandingan menunjukkan bahwa frekuensi kerugian and keuntungan setiap tahun selama periode simulasi menyebabkan nilai akhir perbedaan kerugian and keuntungan. Berdasarkan simulasi dalam penelitian ini, ada beberapa hal yang menentukan praktik pertanian emas. Mereka adalah nilai emas, Pembiayaan untuk Nilai (FTV) rasio, lag and 
jumlah emas digadaikan. Jadi, itu harus diatur atau dibatasi oleh regulator untuk mencegah pelanggan melakukan praktek pertanian emas di bank syariah.

Kata Kunci: Gadai Emas, Pertanian Emas, Pembiayaan untuk Nilai (FTV) and Lag.

\section{Introduction}

Gold with a significant price increases from year to year is considered prospective as a means of investing many commodities that exist (Karim, 2006). The general point of view in the community, gold investments can provide great profits. Some writings on the history of gold price of gold reveal that the price has never been in decrease state, so there is a low risk investment assumption (Subroto, 2013). From the facts above, Ismal (2012) observe that the increase of price that occurred has led to a new trend in the gold pawn sector, that is the increasing volume of gold pawn transactions (Qardh for gold Rahn) in Indonesia.

The increase of gold investment through gold mortgage products also occurs in the Islamic banking industry along with the rise of gold price (Rama, 2011). The trend of gold price that tends to rise in the last fifteen years has shifted the gold pawn paradigm lately. Gold pawning aimed at financing social qardh (tabarru ') and intended for customers who have an urgent need for consumer needs has been shifted into commercial purpose (ijara) (Haryanto, 2012). The above reasons, then bring up the gold investment patterns for the purpose of speculating in a way of pawning in Islamic banks by name investment gold gardening (Syafputri, 2013), although this practice is risky because it uses two-thirds of bank loans(Sahmono,2011).

The increasing volume of gold pawn transactions has been related closely to the increasing number of Islamic banks that open gold pawn services and socialize intensively. In Indonesia, there are at least ten Islamic banks gold pawning services with various names. Those ten Islamic banks can represent mortgage financing qardh gold. Gardening gold investment at sharia banking in general has a pattern as follows:

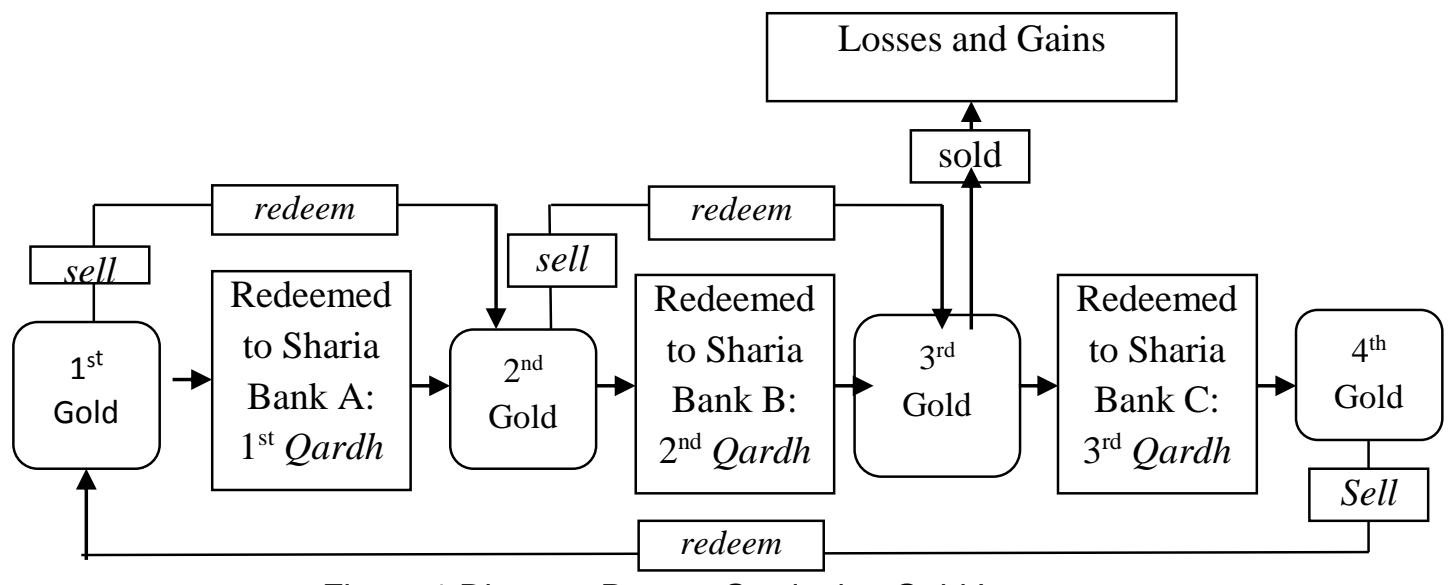

Figure 1 Diagram Pattern Gardening Gold Investment 
Buying and pawning patterns repeatedly to a maximum of four times performed on different Islamic banks, followed by action to sell at the end of the gardening to redeem the pledged gold (see Figure 1). Based on Bank Indonesia regulations, a customer can only pawn gold once on a particular Islamic bank. For the reasons of high profit taking, customers continue to practice gardening gold investment and are no longer realistic in doing investment. The element of high speculation, resulting in many investors suffered heavy losses in a short time when gold prices decline significantly. Investors who are interested in any double profit do not only ignore the Islamic principles, but also no longer consider a high risk of large losses.

Bank Indonesia Circular Letter 14/7 / DPbS / 2012 which refers to the fatwa DSNMUI to overcome the gold pawn problem quite effectively suppress gold investment behavior, but not necessarily resolved in a comprehensive way. Until 2014, the practice of gardening gold is still going on. Kustandar (2013), an inventor of gardening gold investment method stated that the electronic serial book sold over 40,043 copies and seminars held in 2014 is still conducted in many cities and are also still preferred by thousands of people who are interested in promising look profit of gold gardening investment. The number of actual testimony entrepreneurs have been successful in the real sector also indicates this practice will grow back.

The high interest of investment makes the investor are likely to gain profit and ignore the risk of a potential loss. It must be taken into account that this investment is very dependent on fluctuations in the gold price which is not constant these days. In 2013, gold prices declined sharply in August which was at 1,429 dollars (Subroto, 2013). The sharp drop of $28 \%$ during the year 2013 (Deil, 2014) should be taken as a very important notice to be more careful even though in the beginning of 2014 increased strongly higher by $4 \%$ (Rodo, 2014).

Speculation of gardening gold will impact large losses continuously for customers. Investments in the real sector will decline because the funds are allocated for investment in gold commodity. Lack of information for customers about important and fundamental decisive advantages and disadvantages must be resolved. Fluctuations on gold price should be taken into notice by the customers. The level of losses to be carried out and whether or not the profit gain is appropriate over the issued capital must be understood in depth.

It is necessary to give real understanding and knowledge to customers to be careful in the future, and find the complete information more thoroughly, on the ins and outs of the types of investments they choose. Based on the above issues, this study tries to provide a deeper understanding for the gold investors in particular and the public in general, by 
giving scientific proof of the mathematical results (profits or losses) that would be obtained on gardening gold investment. Thus, investors are expected not to make wrong decision on investment.

\section{Literature Review}

Investment

Investments can be understood as a spare or use the time, money or effort for the benefit or higher benefits in the future. However, basically the act of investing is "buy" something that is expected to be "sold back" in the future with a higher value (Suharto, 2013). In general, the investment can be divided into two; investments in financial assets and investments in real assets. (Nasution et al, 2008). In this study, the discussion focused on the type of finance investment using one of the instruments of Islamic banking product i.e. gold pawn. Investment goal is to benefit both the short and long term. Tandelilin (2001) reveals that the purpose or motive of someone to invest is to get a better life in the future, reduce inflationary pressures and as an effort to save on taxes.

Gold Investment in Indonesia

Gold from the past time is regarded as a symbol of wealth and luxury due to the high value and exceptional beauty. Gold is also one commodity that is in demand for investment instruments for promising high returns compared to other commodities and the nature of the liquid (easily sold back) if at any time required.

After centuries, South Africa became the largest supplier of the world's gold. In 2007, China replaced South Africa and became the world's largest gold producer. As gold is a limited natural resource, this production has declined in recent decades, and only grew $2 \%$ per year which is not in a proportion to the increase in needs in which China and India alone accounted for $40 \%$ of total world gold demand. In Indonesia, the paradigm needs of gold to be used as jewelry gold has begun to be replaced by increasing investment holdings precious metals (KLM) in the form of gold bullion the last dozen years (Syafputri, 2012). This research is specially devoted to discuss gold bullion investment through a pattern of repeated pledge or method of gardening gold investment.

\section{Pawn Gold in Bank Sharia}

Pawn is a formal financial institution in charge of channeling funding to grant loan money to people in need (Hadi et al, 2003). While the term mortgage is actually a translation of the word Pand (Dutch language) or pledge or in English is called pawn (Salim, 2007). Prodjodikoro (1960) defines a mortgage as a right acquired by a credited one on a moving object, which to him is given by the debtor or another person on its behalf, 
to secure payment of a debt, and rights given to the credited one to be paid ahead of other credited, taken from the cash revenues goods.

There are five of DSN-MUI fatwa (instruction/guidance) about gold mortgage products in the Indonesian Islamic banking, that regulate these products: Fatwa No.09 / DSN-MUI / IV / 2000 on ljarah Financing, Fatwa No.19 / DSN-MUI / IV / 2001 about al Qardh, Fatwa No.25 / DSN-MUI / III / 2002 is a set of edicts Rahn also associated with gold mortgage products pebankan sharia, Fatwa No.26 / DSN-MUI / III / 2002 on the Gold Rahn, and Fatwa No.79 / DSN-MUI / III / 2011 About Qardh using client funds.

Bank Indonesia Circular Letter No. 14/7 / DPbS February 29, 2012 About the Product Gold Backed Qardh for Sharia Banks and Sharia Business unit

The issue of MUI fatwa No. 79 DSN / DSN-MUI / III / 2011 on qardh using customer funds and considering the development of a gold-backed qardh products is rapidly increasing, potentially increasing the risk for Islamic banking and the abuse of pawning gold as an instrument of speculation (gardening gold). That forms the background of Bank Indonesia issued a policy on a gold-backed qardh implementation of Bank Indonesia Regulation No. 10/17 / PBI / 2008 in the Islamic Banks (BUS) and Islamic Business Unit (UUS) and Sharia Rural Banks (BPRS).

\section{Gardening Gold Investment in Islamic Bank}

Gold gardening investment is a method or technique of investing in gold investment with minimal initial capital but can obtain gold in large quantities by utilizing lien loans of products (rahn) of Islamic banks or pawnshops (Rosnia, 2010). While Werner (2011) reveals that gardening gold investment is buying gold action by using the pledge with the initial capital to buy the first gold bullion, first gold bars then pawned with the pawn value of about $60-80 \%$ and the results are returned to buy gold when the price does not rise or even down then gold bought was mortgaged back and so on. Patterns pawn and gold buying is done over and over in different Islamic banks, therefore it is called gardening gold investment.

The concept of gardening gold investment aims to leverage the gold holdings of the investors. With the increasing trend of gold prices, gold gardening practices is increasing from year to year. Year 2011 is the year in which the volume of gold pawn transactions in Islamic banks is very high due to the activity of investing gardening gold for speculative purposes peaked (Kustandar, 2013). Mechanism of gardening conducted by individual gold investors (individuals) contained in Islamic banking in Indonesia generally has a pattern of "one's own gold-buying mortgaged-pawn-pawn-buy-buy-sell" (Purnomo, 2012). 


\section{Previous Research}

Previous researchers who conduct research on mortgage gardening gold and gold investment in Islamic banks, among others:

1. Ismal (2011) examined the economic impact qardh for rahn against sharia banks, customers and the economy in general. Qardh for gold rahn beyond the limits specified by Bank Indonesia could threaten the position of Capital Adequacy Ratio (CAR) of Islamic banks are concerned and when the price of gold down the potential of Islamic banks have market risk, liquidity, credit, capital and reputation risks because the gold rahn influenced much by movements in the gold price. The impact on the economy in general, qardh for gold rahn only minimal impact because it was not financing pattern of ijarah (business) actually. From the client side, qardh of gold rahn does not affect their economic condition as it is absolutely that gold rahn qardh is allocated for nonproductive financing. While the impact of the economy in general, qardh for gold rahn only gives minimal impact because it is not a true ijarah business financing patterns.

2. Kustandar (2011) did simulative research by using gold mortgage instruments not only in Islamic banks but also in Islamic pawnshop to invest farm gold using fixed price assumption and assumption of gold prices increasing at least $30 \%$ per year can make a profit of more than $80 \%$ per year by only spending a third of the capital of gold that can be purchased.

3. Hapsari (2012) conducted a study on the level of risk and the return as the detection of speculation on gardening gold investments in "X" Islamic banks in Surabaya. This study focused on the rationality of gold gardening investment calculated per 10 days during the 120-day pledge period. Analysis of risk and rate of return on investment indicates speculative investment in gold gardening investment.

4. Amelia (2013) did a comparison of problem solving customers' inability to pay the principal return of sharia gold pawning at PT.BSM and pawnshop Perum sharia services unit. The findings in this study was the difference in the cost of maintenance and administration and policies undertaken in the event of delay in borrowing costs, PT. BSM will make the sale of pledged gold, while pawnshops sharia are doing auctions. While the similarity is rahn and ijara contract agreement.

\section{The Differences with Previous Research}

In contrast to previous studies, this study uses real data in the form of funds qardh pawn gold, gold prices and the exchange rate of Islamic Banking Statistics-Bank Indonesia without using the assumption of price increase of at least 30\% per year and does not take into account ujrah costs and bank charges. The research proves that gardening gold 
investments do not always make a profit, so it is very objective and more relevant to the real conditions on the ground.

\section{Problem Formulation}

Major problem is such as a lack of proper understanding, that gold gardening produce very big profit by initial capital of only one-third of the gold that can be owned at the end. This is the wrong opinion. This way has potential to bring a risk of loss for clients, because most of the capital is from the bank loans (Sahmono, 2011). Customers do not pay attention to the provisions of $\mathrm{BI}$ by continuing to practice the gold gardening. Many investors often suffered unpredictable heavy losses. Incorrect viewpoints and little understanding of the risks on gold gardening can cause continuous practice as speculation activity (Atmaja, 2013).

From the above formulation of the problem, the research questions are: Is gardening gold investments incur losses or gains related to the customer's decisionto purchase or sell gold?

1. Are there any differences in the value of losses and gains on an investment in gold gardening?

2. Are there differences in the number of months of losses and gains on an investment in gold gardening?

3. Is the high number of months and months of profit loss can affect the value of the advantages and disadvantages?

\section{Research Objectives}

1. To analyze the value of the loss or gain related to the customer's decision to buy or sell gold.

2. To analyze the difference in the value of losses and gains on investments of gardening gold.

3. To analyze differences in the amount of losses and gains on an investment in gold gardening.

4. To analyze the effect of the number of months of losses and gains in the value of the losses and gains.

\section{Methods}

\section{Scope of the Study}

This study is devoted to the Qardh financing by looking at the customer side, which the pattern of gold investment with a method of gold gardening investment in Islamic banks 
in Indonesia. This study assumes Qardh Islamic banking financing as a pledge gold investment because of the allocation of funds for gold pawn qardh is included in the financing.

Types of Data and Research Time

The data used in this study is secondary data. While this study has been conducted from February to May 2014.

\section{Data Sources}

The data used in this study is a monthly data in qardh gold pawn United States (USA) for the period of March 2004 to October 2013 obtained from Statistics Center of Islamic banking at Bank Indonesia's website, while the price of gold per ounce per dollar www.goldprice obtained from the website. org.

\section{Model Research}

In this study, the model used is a quantitative mathematical model that simulated gold gardening by using Ismal economics mathematical formulas (2014).

\section{Methods and Data Analysis Tools}

Research on this gold gardening investment used simulation method by using 4 times qardh assumptions on rahn gold and four types of lag (pause) on the execution of 1-month lag, 2-month lag, 3-month lag and 4-month lag to determine whether there is a difference in the yields on each lag. While the analysis tools used to process the data is Microsoft Excel software.

\section{Result and Discussion}

Analyzing gardening gold investment risk in Islamic banks with a simulation method essentially aims to determine the value of benefits that can be achieved and the risk of loss that may be experienced by the customer, as well as the difference every month and every year during the simulation period. In addition to these objectives, this study also aims to determine the intensity or the number of profit months and loss months then to compare both to see the influence that may arise. 
Table 1. Initial value of Gold, Gold Prices and Exchange Rate

\begin{tabular}{|c|r|r|r|}
\hline \multirow{2}{*}{ Year } & \multicolumn{3}{|c|}{ Average per Year } \\
\cline { 2 - 4 } & $\begin{array}{c}\text { Gold Initial Value } \\
\text { (Million IDR) }\end{array}$ & \multicolumn{1}{|c|}{$\begin{array}{c}\text { Gold Price } \\
\text { os/IDR }\end{array}$} & $\begin{array}{c}\text { Exchange } \\
\text { Rate/IDR }\end{array}$ \\
\hline 2004 & 4,396 & 331 & 9,094 \\
\hline 2005 & 7,982 & 359 & 9,751 \\
\hline 2006 & 14,665 & 492 & 9,194 \\
\hline 2007 & 56,266 & 565 & 8,826 \\
\hline 2008 & 114,611 & 703 & 9,758 \\
\hline 2009 & 217,002 & 788 & 10,362 \\
\hline 2010 & 507,268 & 990 & 9,089 \\
\hline 2011 & $2,325,300$ & 1,349 & 8,759 \\
\hline 2012 & $3,007,533$ & 1,676 & 9,351 \\
\hline 2013 & $2,912,960$ & 1,462 & 10,108 \\
\hline Average & 916,798 & 872 & 9,429 \\
\hline \multicolumn{2}{|c|}{ Source: Bank Indonesia and Islamic Banking Statistics } \\
\cline { 2 - 4 }
\end{tabular}

Gold gardening investment simulation in Islamic banking produces some of the findings, both the losses incurred customers and profits generated over the garden gold investing and intensity of annual profit and loss and a comparison of both. The analysis below will explain the advantages and disadvantages profiles of gardening gold in the four scenarios, namely lag 1, lag 2, lag 3 and lag of 3 months.

\section{Comparison of Initial Value Gold Rated After Qardh}

\section{Comparison with First Qardh}

Figure 1 shows the comparison between the value of the initial gold when he first came to the Islamic banks after rate cut Financing to Value (FTV) with qardh first lien. The simulation of gardening gold investment is dynamic, so that after a customer makes a gold gardening process, the initial value of gold continues to increase as shown in the chart with a red line. The initial value of gold is getting higher along with increasing years. The highest initial value of gold is shown in nominal $\mathrm{Rp} 5$ billion while its qardh result reach the highest ever by nearly Rp 9 billion. 


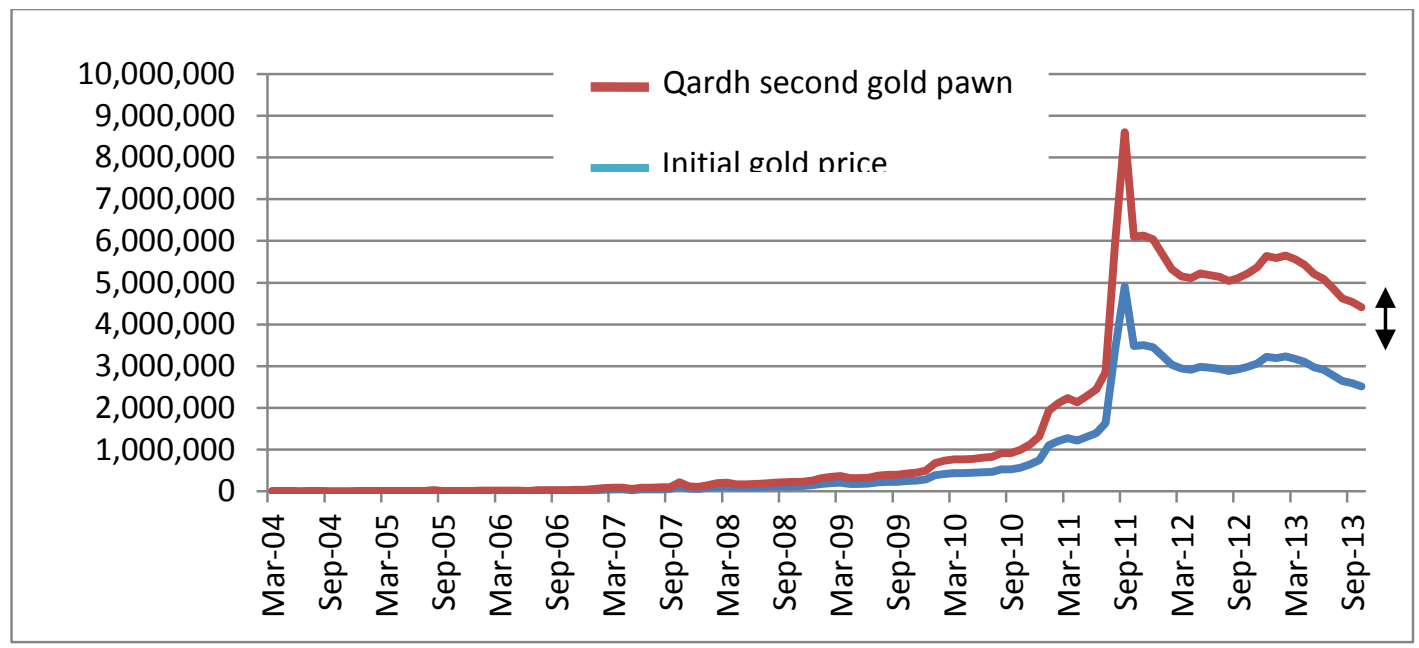

Figure 1 : Gold Initial Value with Gold Pawn First Qardh

\section{Comparison with Second Qardh}

Comparison between the initial gold with second gold mortgage qardh showed higher yield compared to the first mortgage qardh. The highest figure for qardh to reach more than Rp 10 billion, twice bigger than initial funds only Rp 5 billion.

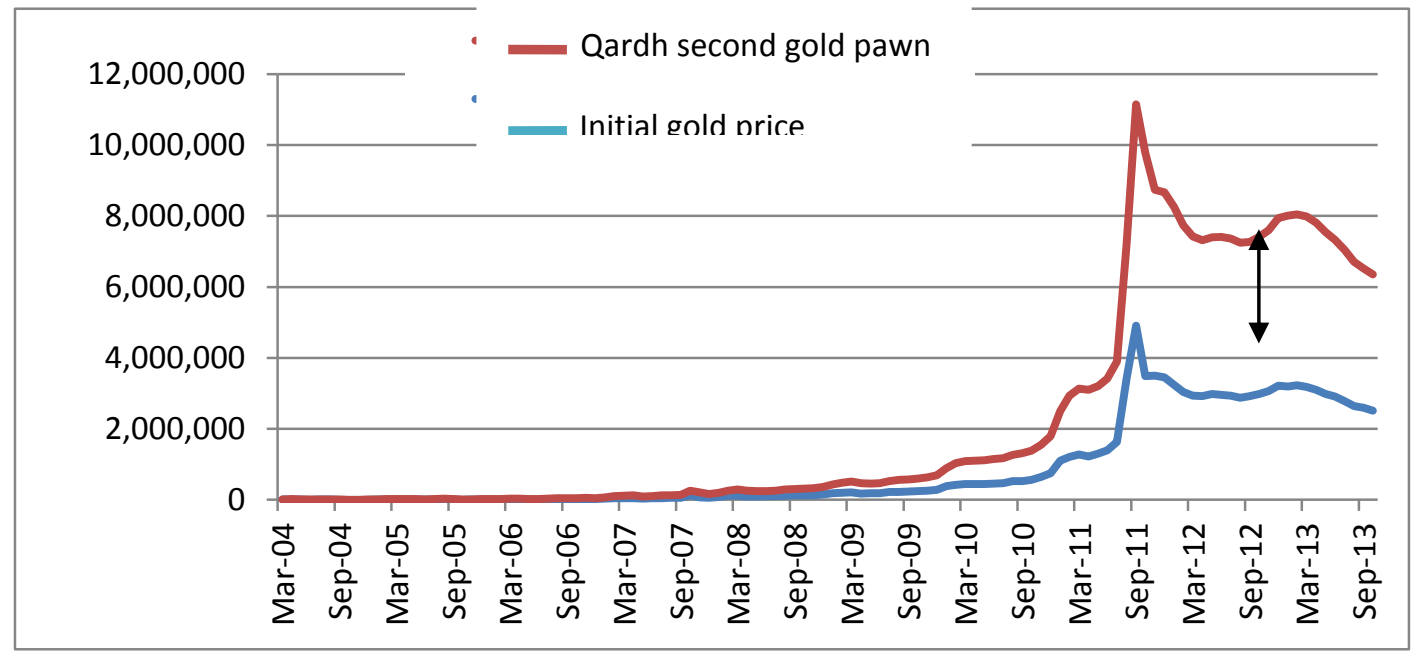

Figure 2 Initial Gold Value with Second Qardh Gold Pawn

\section{Comparison with Third Qardh}

Accumulation of first and second gold qardh mortgage is shown by the third mortgage qardh chart (see Figure 3). When comparable with the initial fund, then the increase of the last amount of funds reaches the highest figure of over Rp 12 billion in 2011. 


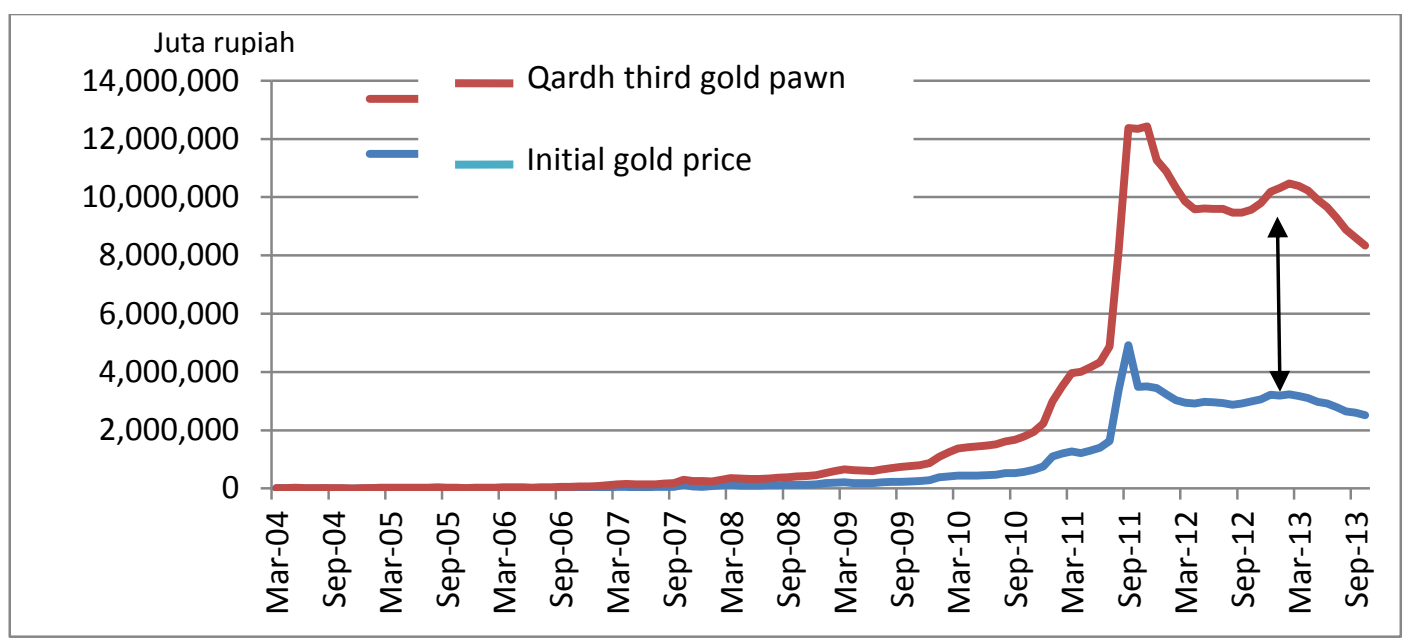

Figure 3. Initial Gold Value with Third Qardh Gold Pawn

The amount of Loss and Gain Value Investing Gardening Gold

The issuance of central bank circular No.14 of 2012 did not discourage customers to invest by utilizing gold mortgage instrument. It happens because people are not aware of the high risks involved due to the tendency to only think of profit only. Law "higher return, higher risk" applies in this gold gardening investment. If the gold price rises customer will have a great advantage, but if the price of gold fall, customers will have to bear greater losses Atmaja (2013).

Table 2. The amount of Loss and Gain Value Investing Gardening Gold

\begin{tabular}{|l|l|l|l|l|l|}
\hline \multirow{2}{*}{ Year } & Initial Gold & \multicolumn{5}{|l|}{ Gains (\%) } \\
\cline { 3 - 6 } & Price I (million) & Lag 1 & Lag 2 & Lag 3 & Lag 4 \\
\hline 2004 & 43,960 & 34,666 & 28,588 & & \\
\hline 2005 & 95,790 & 32,677 & 14,247 & $-17,864$ & $-4,423$ \\
\hline 2006 & 175,981 & 9,929 & 25,128 & $-6,097$ & $-14,971$ \\
\hline 2007 & 675,195 & 161,426 & $-128,619$ & $-171,908$ & $-346,737$ \\
\hline 2008 & $1,375,335$ & 489,208 & 482,738 & $-86,760$ & $-395,065$ \\
\hline 2009 & $2,604,018$ & 886,005 & 236,869 & 93,228 & $-306,340$ \\
\hline 2010 & $6,087,211$ & $1,870,004$ & 112,800 & $-984,270$ & $-1,834,639$ \\
\hline 2011 & $27,903,602$ & $2,535,247$ & $-12,379,000$ & $-14,588,789$ & $-15,680,304$ \\
\hline 2012 & $36,090,400$ & $17,576,597$ & $14,014,953$ & $14,933,210$ & $-763,842$ \\
\hline 2013 & $29,129,600$ & $10,717,363$ & $11,798,922$ & $10,567,188$ & $11,127,054$ \\
\hline $\begin{array}{l}\text { Investment } \\
\text { Result }\end{array}$ & $104,181,092$ & $34,313,121$ & $14,206,626$ & $9,737,938$ & $-8,219,268$ \\
\hline
\end{tabular}

Source: Bank Indonesia statistics, Islamic banks, "has been reprocessed".

Initial value of gold of the same customer does not produce the same loss or gain value in any lag. At lag 1 to lag 3 , there is a result in the form of profits with a downward trend. Lag 1 produce the highest total profit of $\mathrm{Rp} 34,313,121$ trillion, followed lag 2 amounting to less than fifty percent of Rp 14,206,626 trillion and lag 3 and Rp 9,737,938 trillion. Meanwhile, the loss must be experienced at lag 4 of $R p-8,219,268$. The losses suffered during the nine year period of simulation, show a negative final result in lag 4 . 


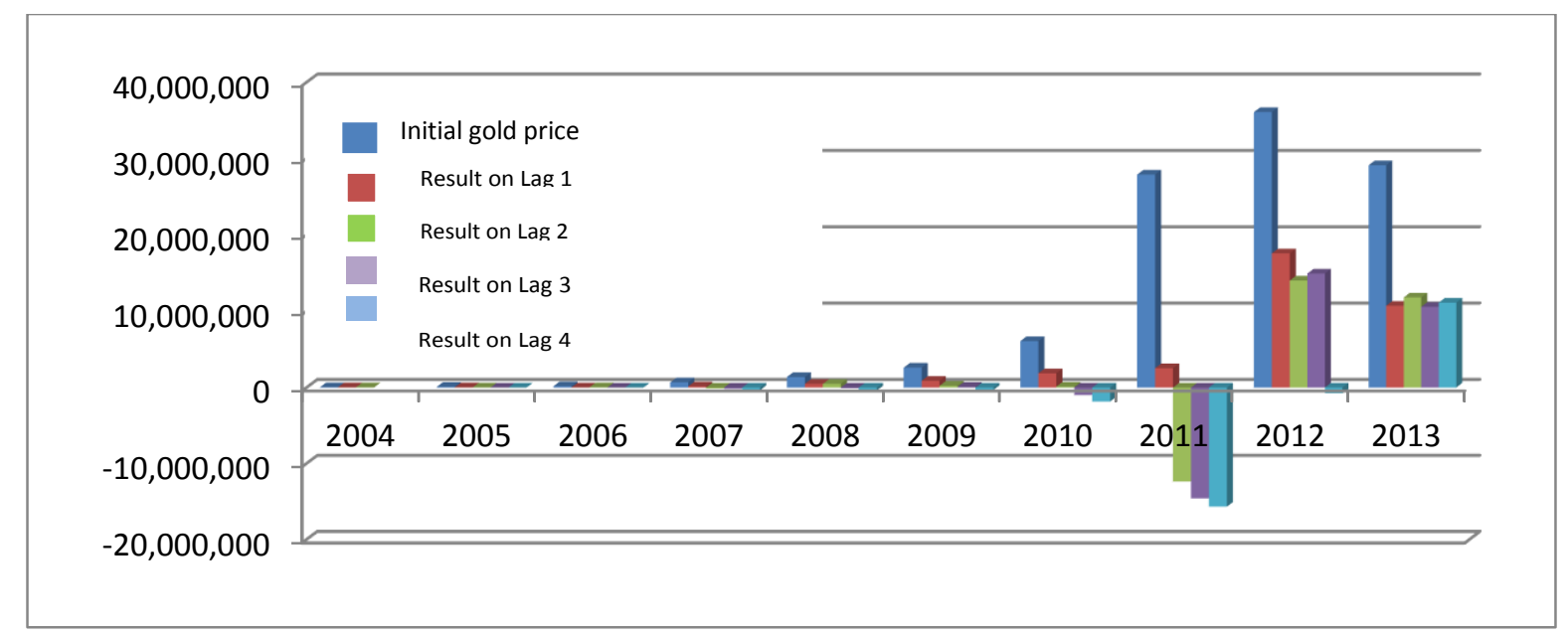

Figure 4 The amount of Value Losses and Gains

Comparison of Losses and Gains Value Against Total Value of Early Gold Per 1 years

Gains experienced in all lag only happen in the year 2012 and 2013. It is inversely proportional to the result in 2011 specifically for the lag 2 to lag 4 , which is the result of a negative result in lag 1 has a positive number. Compared with the initial gold value, small profits earned from year to year distinctively at each lag (see Table 3).

Table 3. Comparative Value of Losses and Gains on Every Lag Per 1 Year

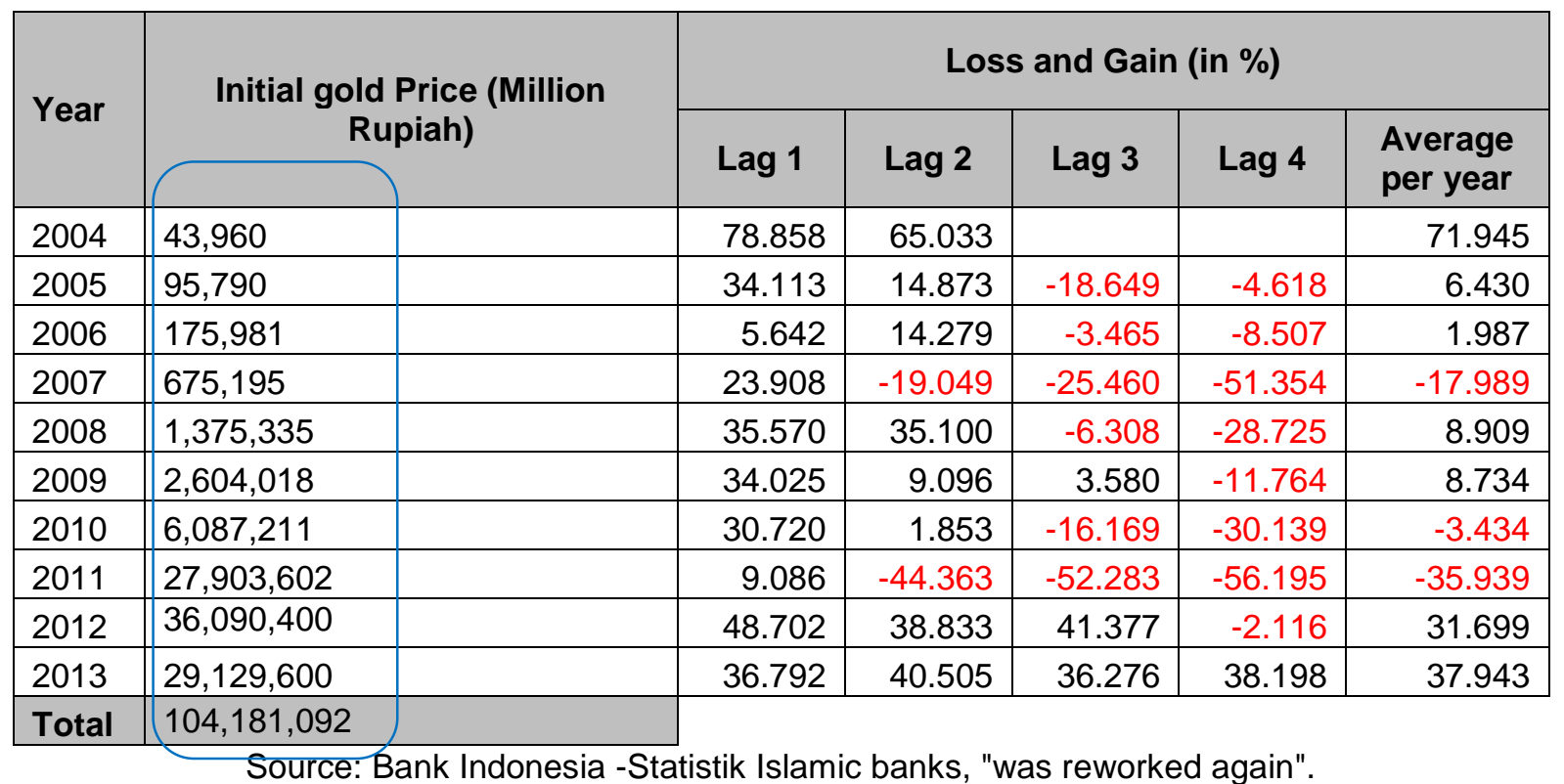

The yield of gold gardening simulation at 1-month lag indicates that in addition to generating the biggest profits on average every year, it also achieved positive returns that are relatively stable in 7 years. One of the reasons is, in normal circumstances, change of gold price is not so drastic in adjacent months. Gold gardening investment at lag 2 produce smaller gains compared with 1-month lag. However, fluctuation in profit annually fluctuates quite high. Even though the average results at lag 2 was not until the 
minus figures as at lag 3 , this is a wake-up call (warning) for customers to begin to be careful because there are years in which the losses suffered by a large percentage.

The proportion of results at lag 3 was indicated negative or losses start to dominate. As at lag 2 and lag 4, the percentage of loss in 2011 actually experienced the greatest loss compared to other years is - $44363 \% 2$-month lag, $-52283 \%$ at lag 3 and at 4 lag 56 195\%. The price of gold in the early growth in 2011 reached the highest price 1,349 dollars per ounce compared to previous years. This is caused by investor concerns on the economic crisis in America and Europe (Rizki, 2011). Interest of investors in the country is getting higher, so that it makes higher gold prices. The loss in 2011 became the largest in the last ten years because customers buy gold at a very high price. While it should be sold at the account after some time pledged in Islamic banks, the price of gold gradually declined in the last quarter of 2011 (Bank Indonesia, 2011).

Meanwhile, the proportion of the yield at lag 4 shows the huge losses during the 9year and 10-year in simulation period. Average loss resulted negative final result in lag 4 at -7893 . This shows how gardening gold at the longest lag is a risky option.

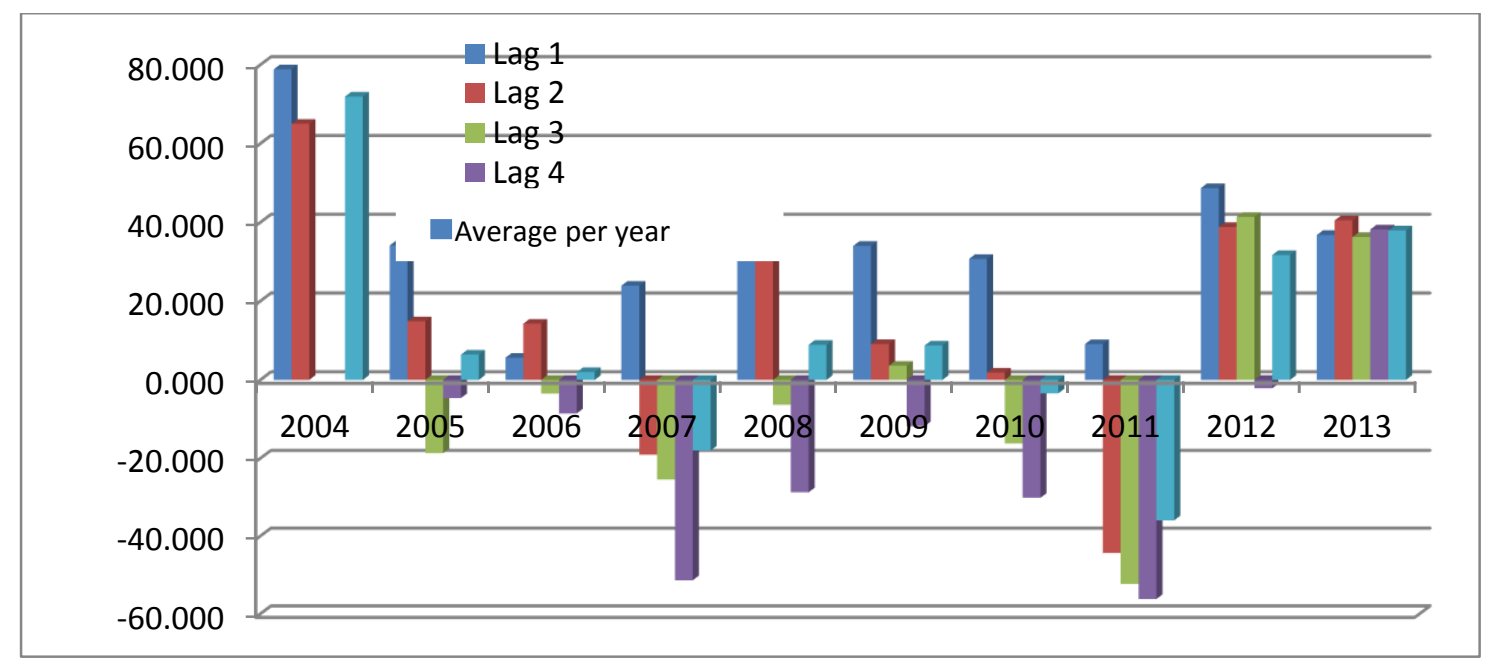

Figure 5. Average Losses and Gains at Each Lag per 1 year (in\%)

The amount of the yield on the column of average on the four lag shows less great profit results. In 2007 with the loss rate -17 989\% and in 2011 the number of losses up to $-3.43 \%$ a year for the high-risk customers. When it is viewed in all lag each year, both positive and negative results indicate that the numbers fluctuate, whereas the results in the previous year tend not to be used as a reference to estimate the results in the next year. 
Comparison of Amount of Losses and Gains Against Total Value of Gold Per Early 10

The table below is different from the previous comparison table comparing the magnitude of the losses and profits value with the initial value on each of the relevant years. Comparisons in this table comparing each outcome divided by the early total value of gold in the decade.

Table 4, Comparative Value of Losses and Gains Lag Per Every 10 Years

\begin{tabular}{|c|c|c|c|c|c|c|}
\hline \multirow{2}{*}{ Year } & \multirow{2}{*}{$\begin{array}{l}\text { Initial Gold } \\
\text { Value } \\
\text { (million Rp) }\end{array}$} & \multicolumn{5}{|c|}{ Loss and Gains (in \%) } \\
\hline & & $\operatorname{Lag} 1$ & Lag 2 & Lag 3 & Lag 4 & $\begin{array}{l}\text { Average } \\
\text { per vear }\end{array}$ \\
\hline 2004 & 43,960 & 0.033 & 0.027 & & & 0.030 \\
\hline 2005 & 95,790 & 0.031 & 0.014 & -0.017 & -0.004 & 0.006 \\
\hline 2006 & 175,981 & 0.010 & 0.024 & -0.006 & -0.014 & 0.003 \\
\hline 2007 & 675,195 & 0.155 & -0.123 & -0.165 & -0.333 & -0.117 \\
\hline 2008 & $1,375,335$ & 0.470 & 0.463 & -0.083 & $\begin{array}{l}-0.379 \\
\end{array}$ & 0.118 \\
\hline 2009 & $2,604,018$ & 0.850 & 0.227 & 0.090 & -0.294 & 0.218 \\
\hline 2010 & $6,087,211$ & 1.795 & 0.108 & -0.945 & -1.762 & -0.201 \\
\hline 2011 & $27,903,602$ & 2.433 & -11.882 & -14.009 & -15.057 & -9.629 \\
\hline 2012 & $36,090,400$ & 16.871 & 13.452 & 14.340 & -0.733 & 10.983 \\
\hline 2013 & $29,129,600$ & 10.287 & 11.325 & 10.147 & 10.685 & 10.611 \\
\hline Average per lag & $104,181,092$ & 32.936 & 13.636 & 9.351 & -7.893 & 12.023 \\
\hline
\end{tabular}

Source: Bank Indonesia statistics, Islamic banks, "has been reprocessed".

In 2012 an average greatest profit had been reached 10 983\%, although at lag 3 had a loss of $-0733 \%$. Next largest average gains had been followed by year 2013 with a yield of $10.611 \%$ and there were no negative numbers in each lag. In a period of ten years, the simulation results showed three times loss, namely in 2007, 2010 and 2011. Average loss in 2011 was the biggest loss, that was $-9629 \%$.

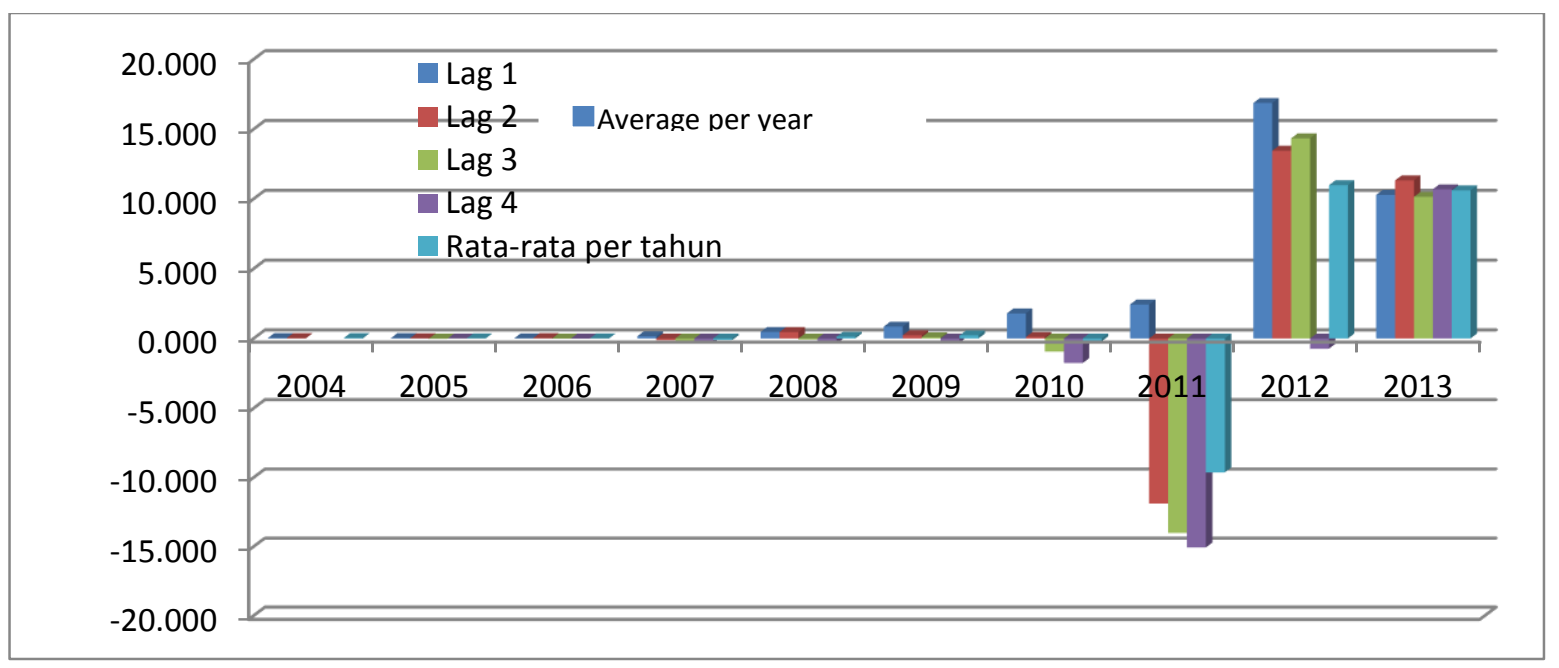

Figure 6. Average Losses and Gains at Each Lag per 10 years (in\%) 
In 2005 and 2006 it was resulted a negative number in the lag 3 and lag 4, but the average end though still showed a small positive number. Average between lag 1 to 4 months' results showed a total of 12 023\% positive percentage. In the form of graphs, significant differences occurred between the years before and after 2010. In 2011 and 2012 was the reversion from a large percentage of losses to a very high percentage of gains.

\section{Total Months of Losses and Gains}

Number of months of losses and gains on gardening gold investments for 116 months (March 2004 - October 2013) was different every year. On investment in 1-month lag, the average comparison month of profit and loss shows unpredictable fluctuations. However, in adjacent years such as 2005 with 2006 and 2012 with 2013 showed the same trend. Volatility in loss and profit at lag 2 months looks pretty high of $100 \%$ in 2004 , to $16.67 \%$ in 2005 and became $0.00 \%$ in 2006 . The rising and falling drastic trend was indicated in subsequent years until 2013.

Table 5. Comparison of Loss Month and Profit Month on Every Lag (in\%)

\begin{tabular}{|l|l|l|l|l|l|}
\hline \multirow{2}{*}{ Year } & \multicolumn{3}{|l|}{$\begin{array}{l}\text { Comparison of Difference of Loss Month and } \\
\text { Profit Month }\end{array}$} & $\begin{array}{l}\text { Difference Average } \\
\text { per year }\end{array}$ \\
\cline { 2 - 5 } & Lag 1 & Lag 2 & Lag 3 & Lag 4 & \\
\hline 2004 & 100.00 & 100.00 & & & 100.00 \\
\hline 2005 & -16.67 & 16.67 & -20.00 & 0.00 & -5.00 \\
\hline 2006 & -16.67 & 0.00 & -33.33 & 0.00 & -12.50 \\
\hline 2007 & 16.67 & -50.00 & -66.67 & -83.33 & -45.83 \\
\hline 2008 & 0.00 & 50.00 & -50.00 & -83.33 & -20.83 \\
\hline 2009 & 66.67 & 16.67 & 16.67 & -50.00 & 12.50 \\
\hline 2010 & 33.33 & -33.33 & -66.67 & -100.00 & -41.67 \\
\hline 2011 & -33.33 & -100.00 & -100.00 & -100.00 & -83.33 \\
\hline 2012 & 50.00 & 66.67 & 33.33 & -16.67 & 33.33 \\
\hline 2013 & 60.00 & 0.00 & 0.00 & 40.00 & 25.00 \\
\hline Average & 26.00 & 7.00 & -32.00 & -44.00 & -3.83 \\
\hline
\end{tabular}

Source: Bank Indonesia -Statistic Islamic banks, "was reprocessed again".

Compared with the 1 and 2 months' lag, volatility in the 3 and 4-month lag does not show very unequal numbers. However, from the table above indicates that the intensity of the average loss dominates, so that it affects negative results. From the average of four lag above shows that gold gardening investment in the period of 2004 to 2013 resulted in a loss more often than profits in each month. 


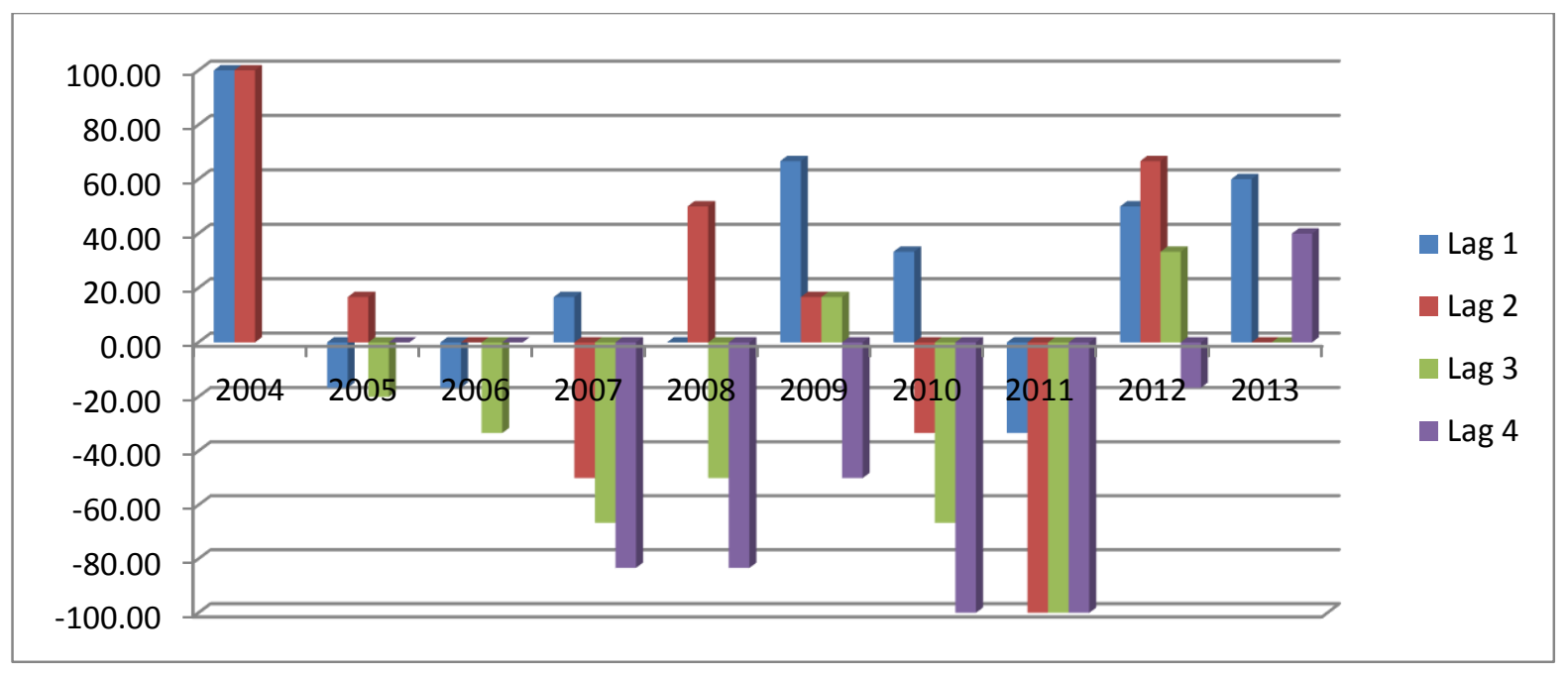

Figure 7. Difference on Disadvantages Month Compared with Advantages Month at Each Lag (in\%)

The important thing in investing is the amount of the yield that will be obtained by an investor, but how often the loss and the profit has, also become an important information so that investors can minimize risk and optimize profits. The above graph gives a clearer picture of the frequency of loss with a large percentage specially in 2011 and 2012, specifically in the 1-month lag. This is a proof that investing in gold gardening in Islamic banks has a very high aspect of speculation with large potential risks.

Comparison of Number of Losses Months and Gains Months with the Amount of Investment Value Results

The amount of gold gardening results in certain months cannot be used as a profit benchmark at the end of the period. This is shown by a comparison table between the number of experiencing gains and losses months in the investment profile of the results below. Comparison of the number of loss/profit months to the amount of investment in 1month lag in general have a positive influence. The average month profit is as much as 47 $273 \%$ and the average yield gain of $3,294 \%$.

Table 6. Total Losses and Gains Months with The Amount of Investment Return (in \%)

\begin{tabular}{|c|c|c|c|c|c|c|c|c|}
\hline \multirow{2}{*}{ Year } & \multicolumn{2}{|c|}{ Lag 1 } & \multicolumn{2}{c|}{ Lag 2 } & \multicolumn{2}{c|}{ Lag 3 } & \multicolumn{2}{c|}{ Lag 4 } \\
\cline { 2 - 9 } & $\mathbf{1}$ & $\mathbf{2}$ & $\mathbf{3}$ & $\mathbf{4}$ & $\mathbf{5}$ & $\mathbf{6}$ & $\mathbf{7}$ & $\mathbf{8}$ \\
\hline 2004 & 100.000 & 0.033 & 100.000 & 0.027 & & & & \\
\hline 2005 & -16.667 & 0.031 & 16.667 & 0.014 & -20.000 & -0.017 & 0.000 & -0.004 \\
\hline 2006 & -16.667 & 0.010 & 0.000 & 0.024 & -33.333 & -0.006 & 0.000 & -0.014 \\
\hline 2007 & 16.667 & 0.155 & -50.000 & -0.123 & -66.667 & -0.165 & -83.333 & -0.333 \\
\hline 2008 & 0.000 & 0.470 & 50.000 & 0.463 & -50.000 & -0.083 & -83.333 & -0.379 \\
\hline 2009 & 66.667 & 0.850 & 16.667 & 0.227 & 16.667 & 0.090 & -50.000 & -0.294 \\
\hline
\end{tabular}




\begin{tabular}{|c|c|c|c|c|c|c|c|c|}
\hline 2010 & 33.333 & 1.795 & -33.333 & 0.108 & -66.667 & -0.945 & -100.000 & -1.762 \\
\hline 2011 & -33.333 & 2.433 & -100.000 & -11.882 & -100.000 & -14.009 & -100.000 & -15.057 \\
\hline 2012 & 50.000 & 16.871 & 66.667 & 13.452 & 33.333 & 14.340 & -16.667 & -0.733 \\
\hline 2013 & 60.000 & 10.287 & 0.000 & 11.325 & 0.000 & 10.147 & 33.333 & 10.685 \\
\hline Total & 260.000 & 32.936 & 66.667 & 13.636 & -286.667 & 9.351 & -400.000 & -7.893 \\
\hline Average & 47.273 & 3.294 & 6.667 & 1.364 & -31.852 & 1.039 & -44.444 & -0.877 \\
\hline
\end{tabular}

Specification:

$1,3,5,7$ : Number of months having loss or gain

$2,4,6,8$ : The amount of loss or gain

In 2004 lag 1 and 2 produce a positive number, then the results are also positive. In the period of 2005, 2006 and 2011 is a typical period. Months of losses and gains do not always produce the same nominal value. Positive results were still obtained in lag 1 is $0.031 \%$ and $0.010 \%$, although the intensity of the loss shows the number of minus -16 $667 \%$. whereas at lag 4, although months of losses and gains is in balance during 2004 and 2005 , that is $0.00 \%$, but actually negative nominal value was obtained $-0004 \%$ and $0.014 \%$.

At lag 2, the negative results began to emerge, although the number of months of losses and profits were also discovered 3 times, i.e. at lag 1 in 2007 and 2011, great losses should also be borne as much as $-0123 \%$ and $-11882 \%$. In contrast to previous unbalanced lag, the table showed the number of months of income or profit was likely to be somewhat according to the amount of investment returns. Average profit at lag 2,13,636 $2 \%$ is from frequency in a profit month of $66667 \%$.

The number of losses months dominates at lag 3 affected in the value of the loss to be borne. The average number of loss months is $-31.851 \%$ and an average yield of smaller gains value than lag 1 and lag 2, is equal to $1.039 \%$. The advantage is very small, close to zero, potential to cause harm if in 2009, 2012 and 2013 are not generated positive percentage rate as shown by the table. Three periods with large positive results, especially in the last two years seems to be a helper at lag 3. The longer the lag, the higher potential losses. This is proven in the lag 3 to lag 4 . When in 2-month lag is still generated a small profit, at lag 3, investors are even starting to bear the loss. Because of the intensity and the amount of loss is high, then the investment in the lag 3 is not the right choice for investors.

The losses suffered by investors in lag 4 with intensity of loss months creates large negative outcomes that must be borne very often. Average intensity of loss is as much as $-44.444 \%$ and an average yield of loss is $-0877 \%$. Total losses at lag $4-7893 \%$ with a frequency in losses reached $-400000 \%$ throughout the last ten years was certainly not a small number. It was considering that investors should allocate funds to gold save costs 
and administration costs in Islamic banks. Frequency in profit months indicated in 2005 and 2006 amounted to $0.000 \%$ and in 2013 amounted to 33,333\%, remained insignificant compared to the amount and frequency of value losses at lag 4. Investors often suffered heavy losses previously unimaginable, when applying gold garden investment (Atmaja, 2013). From the table above, it is clearly illustrated that a gain of $10,685 \%$ in the last year simulation period are not able to compensate for losses to be borne for nine years.

Testing the hypothesis

Testing the four hypotheses proposed, was carried out by comparing the simulation results with a mathematical statement as follows:

Testing the first hypothesis

Mathematical simulations indicate a value of losses and profits of gardening gold, so the research results have been consistent with the hypothesis that "gardening gold investment does not always bring benefits for customers".

Testing the second hypothesis

Mathematical simulations indicate a difference in the value of the loss or gain on any decision of sale in gardening gold, so the answer to the hypothesis is "There is a difference in the value of the loss or gain on any decision on the sale of gold by the customer".

Testing the third hypothesis

The results showed that in month of the losses and profits are not the same at each lag every year, so the hypothesis which states that "the intensity of the loss or gain on each lag every year is always the same" is not true.

The fourth hypothesis testing

The results showed that the number of months of gains and losses is directly proportional to the value of profits (nominal) earned by any lag per year. This was consistent with the hypothesis which states that "The higher the number of months of experiencing losses and gains, the greater the value of gains and losses experienced".

\section{Managerial Implication}

Based on the simulation results of gardening gold, investing in this way can cause harm and not just make profit. Simulation at lag 4 indicates that the losses are often experienced by customers every month and year. Based on the findings of this research, the things that define the practice of gardening is the value of gold, Financing to Value (FTV) ratio, lag (pause) of buying and mortgaging gold and the amount of mortgaged gold. Managerial implication for this research are: 


\section{Bank Indonesia}

The things that define the practice of gardening are the value of gold, Financing To Value (FTV) ratio, lag (pause) buy and pawn gold, the amount of gold that is mortgaged. Thus, such matters should be regulated or restricted to prevent the practice of gardening gold customers in Islamic banks.

Islamic banking

Parties in Islamic banking must comply with and implement operational standards and procedures in accordance with Bank Indonesia in providing mortgage financing gold to customers, it is intended that the potential for speculative practices using gold mortgage instrument does not occur.

\section{Academics}

This study uses real data qardh pawning gold funds, gold prices and the exchange rate. However, it does not take into account the cost of entrusted (ujrah) and administrative costs, in which the amount is different in each Islamic bank. So when they will study further, the academics can do so by considering the above.

\section{Customers}

This study began from the problem of distortion pattern of gold pawn products in Islamic banking, which is supposed to earmark for social purposes (tabarru) which can be an alternative of short-term funds for customers who require urgent funding, into gardening gold investment patterns through lien system. Therefore, customers should continue to use pawn services in Islamic banks for the first pattern, in order to avoid the element of speculation (gharar), which in turn can be detrimental to the client him/herself.

\section{Conclusion}

1. The activity of gardening gold investments are not always profitable. Losses can occur, especially if it is getting longer lag scenario, so it is possible that the client suffered greater losses.

2. There are differences in the loss or gain in any decision on the sale of gold in gold gardening practices. The different number of the initial value of gold and gold price changes, as well as fluctuations in the exchange rate against the dollar led to differences in the loss to be borne, and the value of benefits that can be achieved.

3. There are differences in intensity or the number of months of losses and gains in gold gardening, either every month or every year, on each of the different scenarios lag during the simulation period.

4. Intensity or the number of months of losses and gains affect the amount of the nominal value of losses and gains. The more the number of months of having a surplus in one 
year, the greater the value of the benefits. Similarly the loss, the more the number of months of having a minus in a year, the greater the value of the loss to be borne.

5. Main finding of the study is gardening gold investment can cause harm. Simulation of the lag 4 indicates that customers often had loss of every month and year.

\section{References}

Hadi, Muhammad Sholikul, 2003. Pegadaian Syariah. Penerbit Salemba Diniyah, Jakarta, Edisi pertama.

Karim, Adiwarman. 2004. Bank Islam: Analisis Fiqih and Keuangan. Jakarta: Raja Grafindo Persada.

Nasution, Mustafa Edwin, Huda, Nurul, 2008, Investasi Pada Pasar Modal Syariah, Jakarta, Kencana Prenada Media Group, Edisi Revisi.

Prodjodikoro, Wirjono, 1960, Hukum Perdata Tentang Ha-Hak Atas Benda, Jakarta, Soeroengan.

Salim HS, 2007, Perkembangan Hukum Jaminan di Indonesia, Jakarta, Edisi I, PT. Raja Grafindo Persana, Jakarta, hal 33.

Suharto, Frento T, 2013, Harga Emas Naik Atau Turun Kita Tetap Untung, Jakarta, PT. Elex Media Komputindo.

Syafputri, Ella, 2012, Investasi Emas, Dinar and Dirham, Depok, Penerbit Penebar Plus ${ }^{+}$, Cetakan ke dua.

Tandelilin, Eduardus, 2011, Analisis Investasi and Manajemen Portofolio, Yogyakarta, BPFE.

Ismal, Rifki, 2014, "Regulating Gold Murabahah in Islamic Banking”, International Journal of Commerce and management, Emerald Journal Series, London.

Ismal, Rifki, 2011, "Qardh untuk Rahn Emas", Jurnal Ekonomi Islam Republika, 24 November 2011, hal.24. www.republika.com, Jakarta.

Amelia, Tika, 2013, Perbandingan Penyelesaian Masalah Ketidakmampua Nasabah Emmbayar Pengembalian Pinjaman Pokok Gadai Emas Syariah Pada PT.BSM and Perum Pegadaian Unit Layanan Syariah, Universitas Indonesia, Jakarta.

Deil, Siska Amelia F, Harga Emas Turun Ditimpa Keperkasaan Dolar AS, 5 Februari 2014. http://www.Liputan6.com , diakses Maret 2014.

Hapsari, Anggun Widhi, 2012, Tingkat Risiko dan Pengembalian Sebagai Deteksi Terjadinya Spekulasi Pada Investasi Kebun Emas Di Bank Syariah "X" Surabaya, Universitas Airlangga, Surabaya.

Rosnia, Rindy Antika, 2010, Investasi berkebun emas dalam perspektif ekonomi Islam (studi pada PT. bank Rakyat Indonesia Syariah), UIN Syarif Hidayatullah, Jakarta. 
Kustandar, Rully, 2013, Menjamin Masa Depan: Sembilan Rahasia Evolusi Kebun Emas, e-book Edisi Revisi.

Fatwa No. 09/DSN-MUI/IV/2000 Tentang Pembiayaan ljarah. http://www.mui.or.id

Fatwa No. 19/DSN-MUI/IV/2001 Tentang al Qardh. http://www.mui.or.id

Fatwa No. 25/DSN-MUI/III/2002 Tentang Rahn. http://www.mui.or.id

Fatwa No. 26/DSN-MUI/III/2002 Tentang Rahn Emas. http://www.mui.or.id

Fatwa No. 79/DSN-MUI/III/2011 Tentang Qardh dengan menggunakan anda nasabah. http://www.mui.or.id

Surat edaran Bank Indonesia No.14/7/DPbS/2012 Tentang Produk gadai Beragun Emas di bank Syariah

Atmaja, Lukas Setia, 2013, Hati-Hati Berkebun Emas, http://kolom.kontan. co.id/news/94. diakses 23 Mei 2014.

Haryanto, Muhsin, 2012, Hukum Berkebun Emas, http://muhsinhar.staff.umy. ac.id/hukum-berkebun-emas. Diakses Februari 2014.

Bank Indonesia, 2011, Laporan Perkembangan Perbankan Syariah, http://www.bi.go.id/id/publikasi/perbankan-and stabilitas/syariah/Pages /LPPS 2011.aspx. Diakses 28 Mei 2014.

Kustandar, Rully, 2013, Jurus Cerdas Berkebun Emas, http://www.kebunemas. com. Diakses 17 Maret 2014.

Purnomo, Anto, 2012, Berkebun Emas, Ini Caranya, http://www.readersdigest .co.id/uang/investasi.and.bisnis/berkebun.emas.ini.caranya/004/001/7

Rama, Ali, "Kerancuan Praktik Berkebun Emas" November 2011, www.jurnaekis.blogspot.com, diakses Februari 2014.

Rizki, Devina, 2011, Kebun Emas, Apakah Menguntungkan?, http://devinorizki.com/2011/05/15/kebun-emas-apakah-menguntungkan/. Diakses 17 Maret 2014.

Rodo, Fredy, Harga Emas Terus Membumbung Tinggi, 14 Maret 2014. https://www.antamgold.com/news/read/harga-emas-terus-membumbung-tinggi. diakses Maret 2014 